\title{
GENERALIZED CSISZÁR'S $f$-DIVERGENCE FOR LIPSCHITZIAN FUNCTIONS
}

\author{
Đilda PEČARIĆ, JOSIP PEČARIĆ AND DORA POKAZ
}

\begin{abstract}
We started with the generalization of the Csiszár's $f$-divergence. We stated and proved Jensen's type inequality for $L$-Lipschitzian functions. The results for commonly used examples of $f$-divergences, such as the Kullbach-Leibler divergence, the Hellinger divergence, the Rényi divergence and $\chi^{2}$-distance are derived. Further, we examined two specific averaging functions, previously known in the literature. Finally, we obtained interesting results concerning the Zipf-Mandelbrot law.
\end{abstract}

Mathematics subject classification (2010): 26D10, 26D15.

Keywords and phrases: $f$-divergence, Lipschitzian function, Zipf-Mandelbrot law.

\section{REFERENCES}

[1] S. M. Ali And S. D. Silvey, A general class of coefficients of divergence of one distribution from another, J. Roy. Statist. Soc. series B, 28 (1), (1966), 131-142.

[2] R. Beran, Minimum Hellinger distance estimates for parametric models, Ann. Statist., 5 (1977), 445-463.

[3] Y. J. Cho, M. Matić And J. PeČARIĆ, Inequalities of Jensen's type for Lipschitzian mappings, Comm. on Appl. Nonlinear Analysis 8 (2001), 37-46.

[4] Y. J. CHO, M. MATIĆ AND J. PEČARIĆ, Two mappings in connection to Jensen's inequality, Panamerican Math. J. 12 (1), (2002), 43-50.

[5] I. CSISZÁR, Eine Informationstheoretische Ungleichung und ihre Anwendung auf den Bewis der Ergodizität von Markhoffschen Ketten, Publ. Math. Inst. Hungar. Acad. Sci. 8, (1963), 85-108.

[6] I. CSISZÁR, Information-type measures of difference of probability functions and indirect observations, Studia Sci. Math. Hungar, 2 (1967), 299-318.

[7] S. S. Dragomir, A mapping in connection to Hadamard's inequalities, J. Math. Anal. Appl. 167 (1992), 49-56.

[8] S. S. Dragomir, On Hadamard's inequalities for convex functions, Mat. Balkanicae 6 (4), (1992), 215-222.

[9] S. S. Dragomir, Y. J. Cho And S. S. Kim, Inequalities of Hadamand's type for Lipschitzian mappings and their applications, J. Math. Anal. Appl. 245 (2000), 489-501.

[10] L. Horváth, G. PeČARIĆ AND J. PeČArić, Estimations of $f$ - and Rényi divergences by using a cyclic refinement of the Jensen's inequality, J. Bull. Malays. Math. Sci. Soc. 2017, https://doi.org/10.1007/s40840-017-0526-4.

[11] P. A. KluZa, M. NIEZgoda, On Csiszár and Tsallis type $f$-divergences induced by superquadratic and convex functions, Math. Inequal. Appl. 21, 2 (2018), 455-467.

[12] S. KullBack, Information Theory and Statistics, J. Wiley, New York, 1959.

[13] S. Kullback And R. A. Leibler, On information and sufficiency, Annals Math. Statist., 12 (1951), 79-86.

[14] M. Matić, C. E. M. Pearce, J. PeČArić, Shannon's and related inequalities in information theory, Survey on classical inequalities, editor Themistocles M. Rassias, Kluwer Academic Publ., 2000, $127-$ 164. 
[15] M. Matić, C. E. M. PeArce, J. PeČARić, Some comparison theorems for the mean-value characterization of "useful" information measures, Southeast Asian Bulletin of Mathematics, 23 (1999), $111-116$.

[16] T. Morimoto, Markov processes and the H-theorem, J. Phys. Soc. Jap. 18 (3), (1963), 328-331.

[17] A. ReNYI, On measures of entropy and information, Proc. Fourth Berkeley Symp. Math. Statist. Prob., Vol 1, University of California Press, Berkeley, 1961. 